doi: $10.4274 /$ vhd. 0007

Viral Hepatitis Journal 2017;23(3):71-75

\title{
Hepatitis C Prevalence and Responses to Pegylated Interferon + Ribavirin Treatment Among Prisoners
}

\author{
Mahkumlarda Hepatit C Prevalansının Saptanması ve Pegile Interferon + Ribavirin \\ Tedavi Yanıtlarının Değerlendirilmesi
}

\author{
Hasan Selçuk ÖZGER1', Ömer KARAŞAHIN², Mehmet Armağan TOY1', Sibel IBA YILMAZ², Kenan HIZEL3 \\ ${ }^{1}$ Dr. Ersin Arslan Training and Research Hospital, Clinic of Infectious Diseases and Clinical Microbiology, Gaziantep, Turkey \\ 2 University of Health Sciences, Erzurum Region Training and Research Hospital, Clinic of Infectious Diseases and Clinical Microbiology, Erzurum, Turkey \\ ${ }^{3}$ Gazi University Faculty of Medicine, Department of Infectious Diseases and Clinical Microbiology, Ankara, Turkey
}

\begin{abstract}
Objective: The aim of our study was to identify the hepatitis C prevalence in prisoners and to share experiences of pegylated interferon (peg-IFN) + ribavirin (RBV) treatment.

Materials and Methods: The study was conducted by assessing the records of prisoners between January 2014 and 2016, retrospectively. Patients in whom planned treatments were applied in a given time were determined and, virologic responses at the end of treatment and 6 months after treatment were evaluated. Chi-square test was used and a $p$ value of less than 0.05 was considered statistically significant.

Results: Among prisoners, the anti-hepatitis $\mathrm{C}$ virus (HCV) positivity rate was $7.82 \%$ and HCV-RNA positivity rate was $5.72 \%$. The most common genotype was genotype $3 a$ (66 of 99 patients). End-of-treatment and $6^{\text {th }}$ month sustained virologic response rates were $84.6 \%$ and $80.5 \%$, respectively. In genotype 3a group, endof-treatment and $6^{\text {th }}$ month sustained virologic response rates were found to be higher than other genotypes but not statistically significant.

Conclusion: In our study, which assessed prisoners, the rate of $\mathrm{HCV}$ positivity was higher than hepatitis $\mathrm{C}$ in the general population in Turkey. In accordance with the literature, genotype 3 was the most common genotype among prisoners. Sustained virologic response rates obtained with peg-IFN+RBV treatment suggested that pegIFN treatment should be used with current treatment combinations in prisoners infected with HCV genotype 3.
\end{abstract}

Keywords: Hepatitis C, prisoner, prevalence, pegylated interferon + ribavirin öz

Amaç: Çalışmamızın amacı mahkumlardaki hepatit $\mathrm{C}$ prevalansını belirlemek ve pegile interferon (peg-IFN) + ribavirin (RBV) tedavi deneyimlerini paylaşmaktır.

Gereç ve Yöntemler: Çalışma, Ocak 2014 ve 2016 yılları arasında mahkum kayıtlarını retrospektif olarak değerlendirilerek gerçekleştirildi. Belirlenen sürede planlanan tedavilerin uygulanabildiği hastalar tespit edildi, tedavi sonu ve sonraki 6 . ay virolojik yanıtları değerlendirildi. Ki-kare testi kullanıldı ve $p<0,05$ istatistiksel anlamlıık düzeyi olarak kabul edildi.

Bulgular: Mahkumlarda, anti-hepatit C virüsü (HCV) pozitifliği \% 7,82 ve HCV-RNA pozitifliği \%5,72 idi. En yaygın genotip 3a genotipi (99 hastanın 66'sı) idi. Tedavi sonu ve 6 . ayda devam eden virolojik yanıt oranları sırasıyla \%84,6 ve \%80,5 idi. Genotip 3a grubunda, tedavi sonu ve 6 . ayda devam eden virolojik yanıt oranları diğer genotiplerden daha yüksek bulundu ancak istatistiksel olarak anlamlı değildi.

Sonuç: Mahkumları değerlendiren çalışmamızda HCV pozitifliği, genel olarak Türkiye'deki pozitifliğe göre daha yüksek bulunmuştur. Literatürle benzer olarak, mahkumlarda genotip 3 en yaygın genotip olarak tespit edilmiştir. Peg-IFN+RBV tedavisi ile elde edilen virolojik yanıt oranları, peg-IFN tedavisinin, HCV genotip 3 ile enfekte mahkumlardaki mevcut tedavi kombinasyonları içerisinde yer alması gerektiğini düşündürmektedir.

Anahtar Kelimeler: Hepatit C, mahkum, prevalans, pegile interferon + ribavirin

Özger HS, Karașahin Ö, Toy MA, İba Yılmaz S, Hızel K. Hepatitis C Prevalence and Responses to Pegylated Interferon + Ribavirin Treatment Among Prisoners. Viral Hepat J. 2017;23:71-75.

Address for Correspondence: Ömer Karaşahin MD, University of Health Sciences, Erzurum Region, Clinic of Infectious Diseases and Clinical Microbiology, Erzurum, Turkey Phone: +90 5056634831 E-mail: mrkrshn@hotmail.com ORCID ID: orcid.org/0000-0002-4245-1534 Received: 17.10.2017 Accepted:08.01.2018

${ }^{\circ}$ Copyright 2017 by Viral Hepatitis Society / Viral Hepatitis Journal published by Galenos Publishing House. 


\section{Introduction}

Hepatitis C infections are more common among prisoners compared to the general population. The reported prevalence of hepatitis $\mathrm{C}$ among prisoners is between $2 \%$ and $58 \%$ worldwide, with an average of $30 \%(1,2)$. Despite the high prevalence, the majority of prisoners are unaware of the presence of hepatitis $C$ infection, and the number of prisoners able to receive appropriate treatment is quite low due to psychological and socio-cultural factors (drug addiction, fear, lack of trust) and prison conditions (difficulties accessing healthcare providers) (3).

Although there have been a few studies investigating the prevalence of hepatitis $\mathrm{C}$ among prisoners in Turkey, we did not find any study evaluating treatment response in this group. Therefore, the aim of this study was to determine the prevalence of hepatitis $\mathrm{C}$ in prisoners, which is a growing concern in the management of chronic hepatitis $\mathrm{C}$ infections worldwide, and to share empirical outcomes of older treatments prior to the use of directly-acting antiviral (DAA) therapy.

\section{Materials and Methods}

In this retrospective study, patient records in the infectious diseases outpatient clinics at Gaziantep Dr. Ersin Arslan Training and Research Hospital and Erzurum Training and Research Hospital between January 2014 - 2016 were evaluated. The evaluation included the medical records of all prisoners who presented to the infectious diseases outpatient clinic from the Gaziantep Prison, the Gaziantep E-type Closed Prison Directorate, and the Erzurum Prison Directorate. Patients who tested positive for hepatitis $\mathrm{C}$ virus antibody (anti-HCV) were recorded. These patients' sex, age, HCVRNA values, and HCV genotype were recorded. Viral genotype distributions were compared in terms of geographic variation and age distribution.

The number of HCV-RNA-positive patients who received treatment and the treatment approaches, doses, and duration of the treatment were recorded. It was found that pegylated interferon (peg-IFN) 2a was administered at a fixed dose of 180 $\mathrm{mcg}$ and peg-IFN-2b at a dose of $1.5 \mathrm{mcg} / \mathrm{kg}$. Ribavirin (RBV) dosage was 800 mg/day for genotypes 2 and 3, and weight-based for the other genotypes. Treatment initiated for genotypes 1 and 4 was 48 weeks for a patient showing at least 2 log reduction in HCV-RNA in 12 weeks and HCV-RNA negativity at 24 weeks, while a 24-week regimen was administered for genotypes 2 and 3 . patients who received treatment for the duration planned (completed treatment) were identified and their end-of-treatment and 6-month post-treatment virologic responses (HVC-RNA results) were recorded.

\section{Statistical Analysis}

Sustained virologic response (SVR) rates were compared in terms of viral genotype distributions. The chi-square test was used in comparisons of categorical variables; the Mann-Whitney
$U$ test was used in comparisons of non-categorical variables. The statistical significance level was accepted as $p<0.05$.

\section{Results}

The records of a total of 1.713 prisoners were reviewed, of whom 134 (7.82\%) were positive for anti-HCV. The HCV-RNA positivity rate was $5.72 \%(n=99)$. There was viral replication (HCVRNA positivity) in $73.1 \%$ of anti-HCV-positive patients.

Twenty five $(1.5 \%)$ of the 1.713 prisoners were female and $1.688(98.5 \%)$ were male. Six (4\%) of the anti-HCV-positive prisoners were female. The anti-HCV prevalence was $24.0 \%$ among females and $7.58 \%$ among males.

The mean age of the prisoners was 36.4 (19-72) years. The mean age of the anti-HCV-positive prisoners was 34.8 (19-69) years.

The mean HCV-RNA was 4.034.449 (1.290-17.770.000) IU/ $\mathrm{mL}$. Viral genotype in 99 patients was as follows: 3a in 66 (66.7\%), 1a in 12 (12.1\%), 1b in 19 (19.1\%), 2b in $1(1.0 \%)$, and 4 in $1(1.0 \%)$. The prevalence of infection with genotype $3 a$ was higher among inmates in the Gaziantep prisons (55.9\% vs. 30\%, $\mathrm{p}<0.001)$. Patients infected with genotype $3 a$ had a lower mean age compared to prisoners infected with other genotypes (37.8 vs. 31.9 years, $\mathrm{p}=0.035)$.

Seventy nine $(79.8 \%)$ of the 99 patients were started on peg-IFN (2a or 2b) and RBV (peg-IFN+RBV) therapy. The other 20 patients did not consent to treatment. Treatment was completed in a total of 54 patients and remained incomplete in 25 patients due to non-adherence.

End-of-treatment and 6-month post-treatment SRV rates and genotype distributions of patients who completed treatment are shown in Table 1. Across all genotypes, the SVR rate at 6 months post-treatment was $75.0 \%(n=33)$. Seven patients were considered nonresponsive to treatment, recurrence was observed in 4 patients, and 11 patients were not evaluated for SVR at 6 months post-treatment.

Compared to genotype 1, patients with genotype 3 exhibited higher SVR rates at end-of-treatment (83.3\% vs. 73.7\%, $\mathrm{p}=0.441)$ and 6 months post-treatment $(83.3 \%$ vs. $63.2 \%, p=0.132)$, though the differences were not statistically significant.

\section{Discussion}

It is estimated that approximately 130 to 210 million people worldwide are chronically infected with HCV (4). The prevalence of hepatitis $\mathrm{C}$ varies geographically, ranging from $0.4 \%$ to $0.7 \%$ in developed European nations and increasing to $12.5 \%$ in Egypt $(5,6)$. The reported prevalence of hepatitis C in Turkey is in the range of $0.4 \%-2.2 \%(5,6,7,8,9,10)$. Various other studies conducted in the Eastern and Southeastern Anatolia regions have determined a hepatitis C prevalence of $1.9 \%$ in the Batman area, $2.6 \%$ in the Sanlıurfa area, $0.72 \%$ in the Diyarbakır area, and $0.8 \%$ in the Van area $(11,12,13)$.

The prevalence of hepatitis $\mathrm{C}$ also varies when different risk groups are evaluated. Patients with end-stage kidney failure, transplantation patients, males, intravenous (i.v.) drug addicts, and prisoners are shown to have higher rates of hepatitis $C$ infection $(5,14,15,16)$. The results of a meta-analysis by Larney et al. (17) 


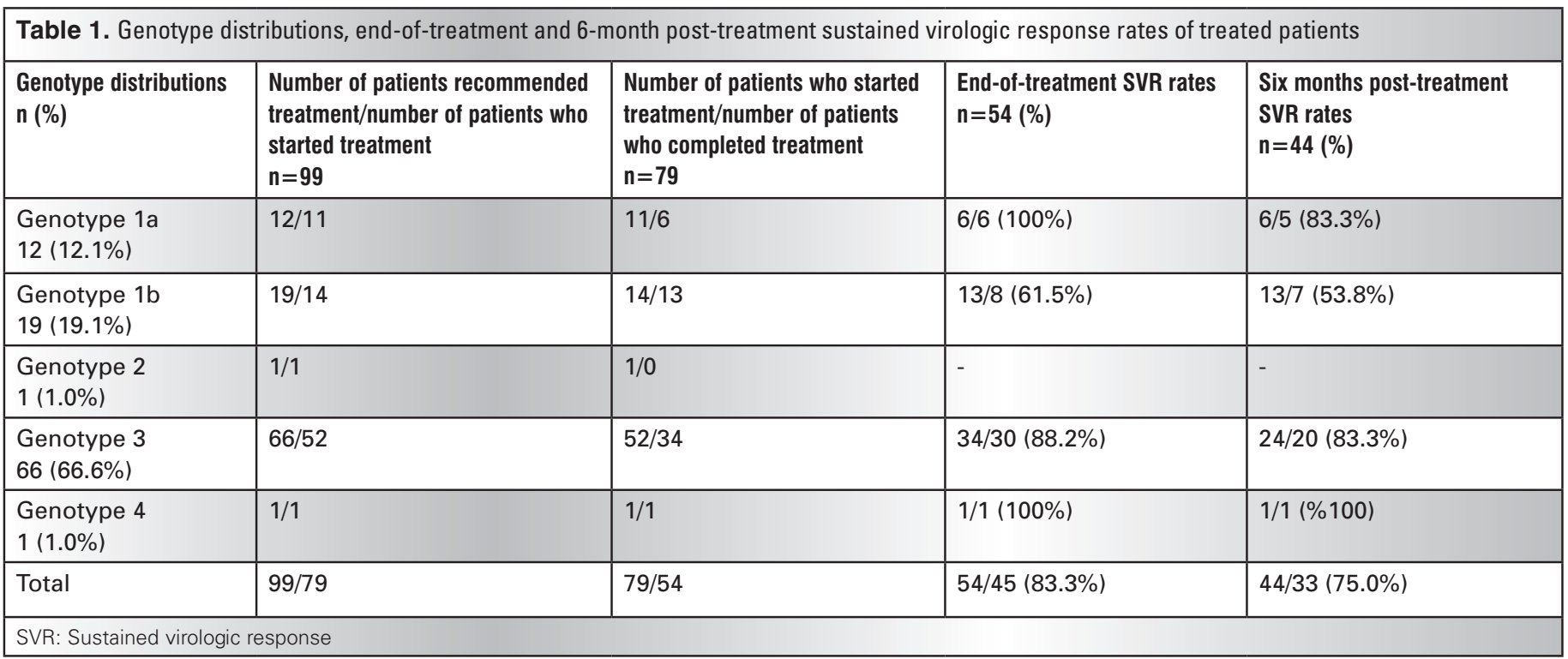

revealed that the prevalence of anti-HCV among prisoners was $26 \%$ worldwide and increased to $64 \%$ among prisoners addicted to i.v. drugs. It was reported in the same study that the incidence of $\mathrm{HCV}$, defined as the occurrence of anti-HCV seroconversion, was $1.4 \%$ in general, but $16.4 \%$ among i.v. drug addicts. According to these data, there are approximately 2.2 million anti-HCV-positive prisoners worldwide, with a large proportion of these in North America and East/Southeast Asia. Zampino et al. (3) showed that the rate of anti-HCV positivity among prisoners varied between $3.0 \%$ and $38 \%$ depending on factors such as geographic region, i.v. drug use, age, duration of imprisonment, and the prisoners' background

There are very few studies on this topic conducted in Turkey. Keten et al. (18) determined an anti-HCV prevalence of $17.7 \%$ among prisoners in the Kahramanmaraş region. In the present study, we evaluated prisoners in 2 different regions and found anti$\mathrm{HCV}$ positivity at a rate of $7.95 \%(n=137)$ and HCV-RNA positivity of $5.86 \%$. These values are higher than previous data regarding the prevalence of hepatitis $\mathrm{C}$ in Turkey and in our region.

Although studies indicate that the most common viral genotype in Turkey is currently genotype 1, Altindis et al. (19) demonstrated increases in the rates of genotype $3(4.78 \%$ to $10.06 \%)$ and genotype 4 (1.3\% to $3.84 \%)$ in recent years (in the periods of 2009 2011 and 2012-2014). Studies on prisoners have also determined genotypes 1 and 3 as the most common. Viral genotype distribution may vary based on the geographic area in which the prison is located and the prisoners' background $(3,20)$. In a study conducted by Keten et al. (18) in the Kahramanmaraş region, which has a higher prevalence of genotype 3 than other regions of Turkey, genotype 3 was the most common viral genotype (68.1\%) among prisoners (21). We also found that genotype 3 was the most common viral genotype (66.7\%) among the prisoners in our study. Studied prisoners from the Gaziantep prison showed higher rates of genotype 3 than studied prisoners from Erzurum, which we attribute to regional variations in genotype distribution. In addition, viral genotype 3 was more prevalent among younger prisoners. These data are consistent with changes in genotype distribution which have been observed recently in Turkey.
Of the 99 patients recommended treatment in our study, SVR was achieved in only 33 at 6 months post-treatment. It appears that inability to persuade patients to undergo treatment, inability to ensure treatment adherence, and noncompliance with posttreatment follow-up are major problems.

Side effects of medications are known to be the leading reason for treatment refusal and discontinuation. It is also known that peg-IFN+RBV therapy can cause side effects which lead to noncompliance with treatment $(22,23)$. Furthermore, numerous factors, such as prison conditions (isolation, frequent prison transfers, etc.), difficulty reaching healthcare providers, and poor diet, increase rates of noncompliance in this patient group, necessitating close follow-up (17). Another reason for treatment interruption is release from prison. It is reported that the average duration of imprisonment is in the range of weeks or months, which makes clinical follow-up difficult, causes interruption of treatment, and prevents post-treatment follow-up $(3,16)$. Therefore, arrangements must be made for prisoners being followed or treated for HCV to continue treatment and follow-up after their release. In addition, it has been noted that the use of curative, completely oral, and short-term (8-12 weeks) DAAs increases prisoners' adherence to treatment (16).

Studies evaluating responses to treatment with peg-IFN+RBV for chronic hepatitis C among prisoners report end-of-treatment SVR rates to be between $28 \%$ and $69 \%$ (3). SVR rates in prisoners infected with genotype 1 varied between $18 \%$ and $43.1 \%$, while those in prisoners infected with genotype 3 were in the range from $50 \%$ to $71.4 \%(3,24,25,26)$. In the present study, SVR rates at 6 months post-treatment were $75 \%$ for all genotypes. We believe that the high SVR rate (83.3\%) among genotype 3 patients, which comprise the majority of prisoners undergoing treatment, should be taken into account when developing treatment algorithms.

Of the DAAs used to treat hepatitis $\mathrm{C}$, only sofosbuvir and daclatasvir are shown to be effective against genotype 3 in vitro (24). Studies of sofosbuvir+RBV combinations and genotype 3 patients have demonstrated that SVR rates vary based on treatment combination and duration. Feld et al. (27) reported a $60.1 \%$ SVR 
rate in genotype 3 patients, most of whom were treated with sofosbuvir+RBV combination for $24 \pm 2$ weeks, with this rate increasing to $84.2 \%$ when peg-IFN was added to the treatment combination. Ampuero et al. (22) also demonstrated in their meta-analysis that adding peg-IFN to a 12-week sofosbuvir+RBV treatment combination resulted in a significant increase in SVR rate (75.2\% to $92.5 \%)$. They stated that the duration of sofosbuvir+RBV treatment must be extended to 24 weeks in order to achieve the same SVR rate that adding peg-IFN provides. Despite effective treatment, the reinfection rate is known to be high, especially among prisoners using i.v. drugs. This emphasizes the importance of a cost-benefit analysis regarding the use of DAAs in prisoners (3). The cost analysis model developed by Martin et al. (28) showed that IFN-free treatments may be cost-effective. Their model included 12-week sofosbuvir+RBV therapy for genotype 3 patients. However, the literature data cited above indicate that this treatment regimen is insufficient to achieve the 95\% SVR rate used in the model $(22,27)$.

\section{Study Limitations}

The most important limitation for our study is to obtain retrospective data. The other, we observed that the prisoners in our study did not attend follow-up visits in the outpatient clinic, and it was not clear why they discontinued treatment.

\section{Conclusion}

Currently, the use of DAAs is recommended for all patient groups, and peg-IFN+RBV therapy is being phased out. However, considering the SVR rates achieved in this and other studies with peg-IFN+RBV, it seems that peg-IFN is still a necessary component in treatment combinations.

Furthermore, simply changing the treatment approach will not eliminate the problems with treatment noncompliance among prisoners in our country, among whom the prevalence of hepatitis $\mathrm{C}$ is high. We believe that treatment and follow-up can be made more effective by adopting a holistic perspective which encompasses the periods both during and after incarceration.

\section{Ethics}

Ethics Committee Approval: Retrospective study.

Informed Consent: It was not taken.

Peer-review: Externally and internally peer-reviewed.

\section{Authorship Contributions}

Surgical and Medical Practices: H.S.Ö., Ö.K., Concept: H.S.Ö., Ö.K., Design: H.S.Ö., Ö.K., Data Collection or Processing: H.S.Ö., Ö.K., S.I.Y., M.A.T, Analysis or Interpretation: H.S.Ö., Ö.K., Literature Search: H.S.Ö., Ö.K., Writing: H.S.Ö., Ö.K., K.H.

Conflict of Interest: No conflict of interest was declared by the authors.

Financial Disclosure: The authors declared that this study received no financial support.

\section{References}

1. Fazel S, Baillargeon J. The health of prisoners. Lancet 2011:377:956-965.
2. Bretana NA, Boelen L, Bull R, Teutsch $S$, White PA, Lloyd AR, Luciani F; HITS-p investigators. Transmission of Hepatitis C Virus among Prisoners, Australia, 2005-2012. Emerg Infect Dis. 2015:21:765-774

3. Zampino R, Coppola N, Sagnelli C, Di Caprio G, Sagnelli E. Hepatitis $C$ virus infection and prisoners: Epidemiology, outcome and treatment. World J Hepatol. 2015;7:2323-2330.

4. European Association of the Study of the Liver. 2011 European Association of the Study of the Liver hepatitis C virus clinical practice guidelines. Liver Int. 2012;32(Suppl 1):2-8

5. Bruggmann P, Berg T, Øvrehus AL, Moreno C, Brandão Mello CE, Roudot-Thoraval F, Marinho RT, Sherman M, Ryder SD, Sperl J, Akarca U, Balık I, Bihl F, Bilodeau M, Blasco AJ, Buti M, Calinas F, Calleja JL, Cheinquer H, Christensen PB, Clausen M, Coelho HS, Cornberg M, Cramp ME, Dore GJ, Doss W, Duberg AS, El-Sayed $\mathrm{MH}$, Ergör G, Esmat G, Estes C, Falconer K, Félix J, Ferraz ML, Ferreira PR, Frankova S, García-Samaniego J, Gerstoft J, Giria JA, Gonçales FL Jr, Gower E, Gschwantler M, Guimarães Pessôa M, Hézode C, Hofer H, Husa P, Idilman R, Kåberg M, Kaita KD, Kautz A, Kaymakoglu S, Krajden M, Krarup H, Laleman W, Lavanchy D, Lázaro P, Marotta P, Mauss S, Mendes Correa MC, Müllhaupt B, Myers RP, Negro F, Nemecek V, Örmeci N, Parkes J, Peltekian KM, Ramji A, Razavi H, Reis N, Roberts SK, Rosenberg WM, Sarmento-Castro R, Sarrazin C, Semela D, Shiha GE, Sievert W, Stärkel P, Stauber RE, Thompson AJ, Urbanek P, van Thiel I, Van Vlierberghe $H$, Vandijck $D$, Vogel W, Waked I, Wedemeyer $H$, Weis N, Wiegand J, Yosry A, Zekry A, Van Damme P, Aleman S, Hindman SJ. Historical epidemiology of hepatitis C virus (HCV) in selected countries. J Viral Hepat. 2014;21(Suppl 1):5-33.

6. van de Laar M, Veldhuijzen I, Hahn S. Hepatitis B and C in the EU neighbourhood: prevalence, burden of disease and screening policies. Stockholm: ECDC 2010;56.

7. Tozun N, Ozdogan O, Cakaloglu Y, Idilman R, Karasu Z, Akarca U, Kaymakoglu S, Ergonul O. Seroprevalence of hepatitis B and Cvirus infections and risk factors in Turkey: a fieldwork TURHEPstudy. Clinical microbiology and infection : the official publicationof the European Society of Clinical Microbiology and InfectiousDiseases 2015;21:1020-1026. (eng).

8. Hahne SJ, Veldhuijzen IK, Wiessing L, Lim TA, Salminen M, Laar Mv. Infection with hepatitis B and C virus in Europe: a systematic review of prevalence and cost-effectiveness of screening. BMC Infect Dis. 2013;13:181.

9. Çeldir M, Kara I, Coşkuner $S$, Keskin B, Küçüker $M$, Orer $H$ Ergönül $\mathrm{O}$. Hepatitis $\mathrm{C}$ prevalence in Turkey: estimation through meta-analysis: Ilayda Arjen Kara. European Journal of Public Health 2014;24:cku163-032.

10. Tosun S. Viral Hepatitlerin Ülkemizdeki Değișen Epidemiyolojisi. ANKEM Derg. 2013;27(Özel Sayı 2):128-134

11. Demirpençe Ö, Tezcan SI, Değirmen $E$, Mert $D$, Gümüş $A$, Celen MK. Seroprevalence of HAV, HBV, HCV and HIV in People Admitted to Batman State Hospital. Viral Hepat J. 2012;18:6-10.

12. Gültepe B, Dülger AC, Aytemiz E. Epidemiology of the hepatitis $C$ infection in Van's region. Eastern Journal of Medicine. 2013;18:123-126

13. Mıstık R. Türkiye'de viral hepatit epidemiyolojisi yayınların irdelenmesi. Içinde: Tabak F, Tekeli E (eds). Viral Hepatit 2007. 1. Baskı. İstanbul: Viral Hepatitle Savașım Derneği, 2007. p. 10-50.

14. Ozer Etik D, Ocal $S$, Boyacioglu AS. Hepatitis $C$ infection in hemodialysis patients: A review. World J Hepatol. 2015;7:885895

15. Serdengeçti K, Gultekin S, Mehmet Riza A, Nurhan S. Registry of the nephrology, dialysis and transplantation in Turkey. Pub Turk Soci of Neph Istanbul 2009:1-76.

16. Martin NK, Vickerman P, Dore GJ, Hickman M. The hepatitis C virus epidemics in key populations (including people who inject 
drugs, prisoners and MSM): the use of direct-acting antivirals as treatment for prevention. Curr Opin HIV AIDS. 2015;10:374-380.

17. Larney S, Kopinski H, Beckwith CG, Zaller ND, Jarlais DD, Hagan $H$, Rich JD, van den Bergh BJ, Degenhardt L. Incidence and prevalence of hepatitis $C$ in prisons and other closed settings: results of a systematic review and meta-analysis. Hepatology. 2013;58:1215-1224.

18. Keten $D$, Emin Ova M, Sirri Keten H, Keten A, Gulderen E, Tumer S, Caliskan A, Kulotu S. The Prevalence of Hepatitis B and C Among Prisoners in Kahramanmaras, Turkey. Jundishapur $\mathrm{J}$ Microbiol. 2016;9:e31598.

19. Altindis M, Dal T, Akyar I, Karatuna O, Gokahmetoglu S, Ulger ST, Şener AG, Özdemir M, Aydoğan S, Kuşkucu MA, Midilli K, Otlu B, Celen MK, Buruk K, Güdücüoğlu H. Six-year distribution pattern of hepatitis $\mathrm{C}$ virus in Turkey: a multicentre study. Biotechnology Biotechnology Equipment. 2016;30:335-340.

20. Mahowald MK, Larney S, Zaller ND, Scharff N, Taylor LE, Beckwith CG, Noska A, Rich JD, Flanigan TP. Characterizing the Burden of Hepatitis C Infection Among Entrants to Pennsylvania State Prisons, 2004 to 2012. J Correct Health Care. 2016;22:41-45.

21. Caliskan A, Kirisci O, Ozkaya E, Ozden S, Tumer S, Caglar S, Guler SA, Senol H. Distribution and predominance of genotype 3 in hepatitis $C$ virus carriers in the province of kahramanmaras, Turkey. Hepat Mon. 2015;15:e25142.

22. Ampuero J, Reddy KR, Romero-Gomez M. Hepatitis C virus genotype 3: Meta-analysis on sustained virologic response rates with currently available treatment options. World J Gastroenterol. 2016;22:5285-5292.

23. Fried MW. Side effects of therapy of hepatitis $C$ and their management. Hepatology. 2002;36(5 Suppl 1):237-244.

24. Farley JD, Wong VK, Chung HV, Lim E, Walters G, Farley TA, Yoshida EM. Treatment of chronic hepatitis $\mathrm{C}$ in Canadian prison inmates. Can J Gastroenterol. 2005;19:153-156.

25. Maru DS, Bruce RD, Basu S, Altice FL. Clinical outcomes of hepatitis $\mathrm{C}$ treatment in a prison setting: feasibility and effectiveness for challenging treatment populations. Clin Infecti Dis. 2008;47:952-961.

26. Chew KW, Allen SA, Taylor LE, Rich JD, Feller E. Treatment outcomes with pegylated interferon and ribavirin for male prisoners with chronic hepatitis C. J Clin Gastroenterol. 2009;43:686-691.

27. Feld JJ, Maan R, Zeuzem S, Kuo A, Nelson DR, Di Bisceglie AM, Manns MP, Sherman K, Frazier LM, Sterling R, Mailliard M, Schmidt M, Akushevich L, Vainorius M, Fried MW. Effectiveness and Safety of Sofosbuvir-Based Regimens for Chronic HCV Genotype 3 Infection: Results of the HCV-TARGET Study. Clin Infect Dis. 2016;63:776-783.

28. Martin NK, Vickerman P, Brew IF, Williamson J, Miners A, Irving WL, Saksena S, Hutchinson SJ, Mandal S, O'Moore E, Hickman $M$. Is Increased Hepatitis C Virus Case-Finding Combined With Current or 8-Week to 12-Week Direct-Acting Antiviral Therapy Cost-Effective in UK Prisons? A Prevention Benefit Analysis. Hepatology. 2016;63:1796-1808. 